\title{
Tinjauan Etik Upaya Promotif Kesehatan untuk Menunda ke Dokter Kecuali Kasus Berpotensi Gawat Darurat atau Pelayanan yang Tidak Dapat Ditunda
}

\author{
Broto Wasisto ${ }^{\mathrm{I}}$, Nurfanida Librianty ${ }^{\mathrm{I}, 2}$, Fadlika Harinda \\ ${ }^{\mathrm{I}}$ Majelis Kehormatan Etik Kedokteran Pengurus Besar Ikatan Dokter Indonesia \\ ${ }^{2}$ Fakultas Kedokteran Universitas Pembangunan Nasional Veteran Jakarta
}

\author{
Kata Kunci \\ Kunjungan, pandemi, promosi kesehatan, \\ rumah sakit, tunda
}

\section{Korespondensi}

librianty@gmail.com

Publikasi

(C) 2020 JEKI/ilmiah.id

\section{DOI}

I0.26880/jeki.v4i2.50

Tanggal masuk: I2 Juli 2020

Tanggal ditelaah: 28 Agustus 2020

Tanggal diterima: 3 September 2020

Tanggal publikasi: 4 September 2020
Abstrak Dalam situasi pandemi, tidak dapat dipungkiri bahwa pelaksanaan berbagai hal tentunya tidak dapat terselenggara secara ideal sebagaimana di masa sebelum adanya pandemi. Hal ini juga berlaku dengan kondisi layanan kesehatan. Pandemi COVID-i9 menyebabkan berbagai adaptasi dalam aspek pelayanan kesehatan. Hal tersebut perlu dilakukan demi menekan risiko penularan penyakit, memberikan perlindungan bagi tenaga kesehatan dan pekerja di layanan kesehatan lainnya, serta memberikan pelayanan kesehatan bagi orang sakit lainnya secara optimal. Sebagai upaya pelayanan kesehatan holistik, dokter berperan dalam upaya promotif dengan melakukan edukasi kepada masyarakat yang dalam konteks ini adalah edukasi mengenai penundaan kunjungan ke fasilitas layanan kesehatan kecuali pada kondisi-kondisi di mana terdapat potensi gawat darurat dan pelayanan yang tidak dapat ditunda seperti imunisasi anak. Untuk menjaga agar kebutuhan pelayanan kesehatan masyarakat tetap terpenuhi, masyarakat diimbau untuk memanfaatkan layanan konsultasi kesehatan secara daring atau telekonsultasi dengan dokter sehingga masyarakat tetap bisa memperoleh nasihat dokter secara efektif dan efisien tanpa harus berhadapan dengan risiko penularan penyakit dengan kunjungan ke rumah sakit. Namun, pada kondisi dengan potensi gawat darurat, masyarakat tetap diimbau untuk segera melakukan kunjungan agar kondisi tersebut dapat segera ditangani oleh dokter yang berwenang.

Abstract It cannot be denied that the implementation of various things in pandemic period cannot be carried out in an ideal manner as in the pre-pandemic period. This also applies to health services. The COVID-I9 pandemic has caused various adaptations in aspects of health services. These need to be done to reduce the risk of disease transmission, provide protection for health workers, and provide optimal health services for other sick people. As a holistic approach in health service doctors play a role in health promotion by providing education to the public, which in this context is education about postponing visits to health care facilities, except in conditions where there is potential for emergency situations and services that cannot be postponed such as child immunization. Keeping the needs of public health services fulfilled, the public is encouraged to take advantage of online health consultation services or teleconsultation with doctors so that people can still get doctor's advice effectively and efficiently without having to deal with the risk of disease transmission by a hospital visit. However, in a condition with a potential emergency, the public is advised to immediately make a visit so that the condition can be immediately treated by the authorized doctor.

\section{Wabah penyakit menular didefinisikan} dalam peraturan menteri kesehatan nomor 1501/MENKES/PER/X/2010 sebagai "kejadian berjangkitnya penyakit menular dalam masyarakatyang jumlah penderitanya meningkat secara nyata melampaui keadaan lazim pada waktu dan daerah tertentu serta menimbulkan kerugian". ${ }^{1}$ Upaya penanggulangan wabah memiliki dua tujuan pokok, yaitu (1) menekan angka kematian akibat wabah melalui pengobatan dan mencegah penularan serta (2) membatasi penyebaran penyakit agar penderita tidak bertambah dan wabah tidak meluas lebih lanjut lagi. ${ }^{2}$ Berbagai upaya pencegahan penyakit perlu dilakukan untuk memberikan perlindungan kepada orang sehat terutama yang berisiko tinggi tertular penyakit. Penyuluhan kepada masyarakat melalui kegiatan komunikasi 
persuasif dan edukatif sangat berperan dalam memberikan pemahaman mengenai upaya pencegahan penularan yang dapat dilakukan untuk melindungi diri sendiri atau menularkan kepada orang lain. ${ }^{2}$

Setiap individu memiliki hak untuk mendapatkan pelayanan kesehatan sesuai kebutuhan medisnya. Dokter dan tenaga kesehatan lain pun juga memiliki kewajiban untuk menjalankan layanan kesehatan sesuai dengan standar profesi dan prosedur operasional yang telah disepakati oleh kolegium profesi secara adil tanpa memandang status sosial. ${ }^{3}$ Pada masa pandemi COVID-19, demi menekan risiko paparan dengan pasien COVID-19, haruslah dilakukan upaya promotif seperti anjuran menunda kunjungan ke dokter kecuali pada kondisi dengan potensi gawat darurat.

Indonesia merupakan negara dengan penduduk sebesar 268.074.565 jiwa dengan laju pertambahan penduduk per 2019 sebesar 3.06 juta jiwa per tahun. ${ }^{4}$ Meskipun. Laju pertambahan penduduk tersebut sejak tahun 2015 trennya menurun, Indonesia masih menempati peringkat ke-4 negara dengan jumlah penduduk terbanyak di dunia, di bawah China, India, dan Amerika Serikat. ${ }^{5}$ Sayangnya, hingga saat ini jumlah fasilitas layanan kesehatan di Indonesia masih jauh dari kata ideal. Berdasarkan data yang termuat dalam profil kesehatan Indonesia tahun 2019 rerata ketersediaan tempat tidur rumah sakit per 1.000 penduduk adalah 1,18. ${ }^{4}$ Dalam kondisi normal, jumlah rerata tersebut sudah memenuhi standar menurut organisasi kesehatan dunia (WHO) yaitu minimal 1 berbanding 1.000 penduduk. Akan tetapi, pada kondisi pandemi, jumlah tersebut perlu ditingkatkan mengingat potensi terjadinya ledakan jumlah orang sakit di waktu yang bersamaan (surge capacity). ${ }^{6}$

Bila dilihat lebih rinci, rasio tempat tidur rumah sakit per 1000 penduduk di beberapa wilayah memang sudah memenuhi standar. Namun, pada beberapa wilayah seperti Riau, Kalimantan Tengah, Sulawesi Barat, Lampung, Jawa Barat, Banten, Nusa Tenggara Timur, dan Nusa Tenggara Barat, standar tersebut belum tercapai. ${ }^{4}$ Dengan kondisi demikian tentu akan timbul hendaya dalam memenuhi kebutuhan pelayanan kesehatan yang ada, terlebih pada kondisi pandemi. Dapat dibayangkan seberapa terbatasnya fasilitas di kota-kota kecil di wilayahwilayah tersebut dengan jumlah penduduk yang juga tidak sedikit. Pada tanggal 21 hingga 29 Agustus 2020 laju pertambahan kasus COVID-19 di Indonesia masih mencapai 2000 - 3000 kasus terkonfirmasi positif per harinya dengan case fatality rate mencapai $4.35 \%{ }^{?}$ Dengan tren yang masih cenderung naik, bisa diperkirakan COVID-19 kemungkinan masih akan berlangsung hingga penghujung tahun 2020. Oleh karena itu, perlu diberlakukan triase dan prioritas perawatan mengingat daya tampung fasilitas yang terbatas.

Menurut peraturan Menteri Kesehatan Republik Indonesia nomor 4 tahun 2018 tentang Kewajiban Rumah Sakit dan Kewajiban Pasien pasal 26, dalam menerima pelayanan dari rumah sakit, pasien memiliki kewajiban untuk mematuhi peraturan rumah sakit dan menghormati hak pasien lain, pengunjung maupun hak tenaga kesehatan serta petugas lainnya yang bekerja di rumah sakit. ${ }^{8}$ Dalam hal ini, bila kita kembalikan kepada hak pasien yang tercantum dalam Undang-undang Nomor 20 Tahun 2004, tercantum bahwa pasien berhak mendapat layanan kesehatan yang sesuai dengan kebutuhannya, maka setiap pasien wajib untuk menghormati hak pasien lain yang memiliki hendaya atau kendala lebih mendesak untuk mendapatkan layanan kesehatan dalam konteks keterbatasan fasilitas kesehatan. ${ }^{3}$

Ikatan Dokter Indonesia (IDI) telah mengeluarkan imbauan bagi masyarakat agar menunda kunjungan ke fasilitas kesehatan kecuali terdapat kondisi gawat atau kondisi yang memerlukan pemeriksaan dan tindakan medis segera. Bukan tidak mendasar, imbauan tersebut dikeluarkan mengingat kondisi keterbatasan fasilitas kesehatan yang sedemikian rupa dan demi menekan risiko penularan virus SARS-CoV-2. Masyarakat juga diimbau untuk memanfaatkan fasilitas pelayanan kesehatan yang berbasis telekonsultasi atau konsultasi melalui daring, dan layanan homevisit care untuk berkonsultasi dengan dokter secara intensif. Demi mendukung upaya mematuhi protokol kesehatan yang digalakkan pemerintah, IDI juga 
mengimbau pengurangan kunjungan pasien ke rumah sakit dan diberlakukannya pembatasan jumlah pasien dalam layanan rawat jalan per harinya. ${ }^{9}$

Secara umum, gawat didefinisikan sebagai kondisi kritis dan/atau mengkhawatirkan karena dapat mengancam nyawa. Adapun darurat didefinisikan sebagai keadaan sukar (sulit) yang terjadi tanpa bisa diduga dan memerlukan penanggulangan segera. ${ }^{10}$ Merujuk kepada definisi tersebut, kondisi yang berpotensi gawat darurat tentunya bersifat sangat umum dan akan berbeda antar satu individu dengan individu lain mengingat kondisi medis yang dimiliki serta keadaan penyulit yang menyertai. Oleh karena itu, meskipun kunjungan langsung ke fasilitas layanan kesehatan diimbau untuk ditunda sementara waktu, konsultasi secara daring tetap perlu dan boleh dilakukan agar segala risiko dapat terdeteksi lebih awal oleh dokter yang berwenang.

Dalam Peraturan Konsil Kedokteran Indonesia Nomor 74 Tahun 2020 tentang kewenangan klinis dan pratik kedokteran melalui Telemedicine pada masa Pandemi Covid-19 di Indonesia dikatakan bahwa praktik kedokteran berbasis aplikasi sistem elektronik merupakan bagian dari telekonsultasi yang boleh diberikan oleh dokter dengan tetap memperhatikan prinsip komunikasi efektif dan menerapkan prinsip kerahasiaan medis pasien. Layanan telekonsultasi tersebut dapat diselenggarakan dalam moda daring tulisan, suara, maupun video. ${ }^{11}$

Kelebihan-kelebihan telekonsultasi, antara lain:

1. Akses dengan dokter lebih mudah dengan mengunjungi laman situs daring atau mengunduh program aplikasi di telepon genggam

2. Dapat segera mengetahui pertolongan pertama ketika sakit

3. Rujukan online untuk kasus emergensi

4. Membuat janji temu lebih mudah

Beberapa hal yang perlu disiapkan pada saat akan melakukan telekonsultasi antara lain menyiapkan catatan riwayat penyakit dan daftar obat yang sedang dikonsumsi. Persiapan ini dilakukan agar telekonsultasi dapat berlangsung secara efisien.

Selain kondisi berpotensi gawat darurat, imbauan penundaan kunjungan ke layanan kesehatan tidak berlaku pada kondisi adanya kebutuhan pelayanan yang tidak dapat ditunda seperti pelaksanaan program imunisasi. Sesuai dengan imbauan Pengurus Besar Ikatan Dokter Anak Indonesia (PB-IDAI), anak-anak harus tetap mendapatkan imunisasi lengkap sesuai jadwal yang direkomendasikan. Oleh karena itu, PB-IDAI mengimbau untuk mengalihkan pelaksanaan imunisasi anak ke klinik imunisasi atau puskesmas terdekat untuk menghindari kunjungan ke rumah sakit. Indonesia Technical Advisory Group on Immunization (ITAGI) atau Komite Ahli Penasehat Imunisasi Nasional, menyarankan untuk memberikan imunisasi ganda (multiple injection) dengan syarat tertentu untuk mengurangi kunjungan ke tempat pelayanan imunisasi dan mempercepat anak untuk mendapatkan kelengkapan imunisasi pada masa pandemi, tentunya dengan mengikuti prosedur protokol kesehatan. ${ }^{12}$

\section{Tinjauan Etik}

Standar pelayanan yang baik mewajibkan seorang dokter dalam pengambilan keputusan profesional bersikap independen. Segala nasihat dokter juga hanya diberikan untuk kepentingan dan kebaikan pasien tersebut. Hal ini tercantum dalam Kode Etik Kedokteran Indonesia (KODEKI) Tahun 2012 pasal 2 dan $5 .{ }^{13}$ Dalam konteks ini, dokter perlu memberikan nasihat untuk menunda kunjungan ke rumah sakit demi kebaikan pasien. Risiko paparan SARS-CoV-2 yang tinggi di rumah sakit menjadi alasan pertama mengapa dokter perlu mengambil keputusan tersebut. Yang kedua, pasien-pasien dengan kondisi medis tertentu yang juga disertai keadaan-keadaan penyulit medis memiliki kerentanan yang lebih besar dibandingkan orang dengan kondisi tanpa penyulit medis. Untuk pasien dengan penyakit kronis terkendali, misalnya pasien diabetes dan hipertensi yang terkontrol, dapat diberikan obat untuk dua bulan sehingga yang biasanya kontrol setiap bulan dapat dijadwalkan menjadi setiap dua bulan. 
Sejatinya, dalam KODEKI tahun 2012 pasal 10 juga menyatakan bahwa seorang dokter wajib menghormati hak dan menjaga kepercayaan pasien. ${ }^{13}$ Untuk itu, upaya promotif menunda kunjungan ke dokter dan mengalihkan konsultasi ke dalam bentuk daring pada kondisikondisi yang tidak berpotensi gawat darurat menjadi perlu dilakukan. Dengan demikian, hak pasien untuk mendapatkan pelayanan kesehatan sesuai kebutuhannya juga tetap dapat terlaksana. ${ }^{3}$ Dalam konteks pelayanan kesehatan yang holistik, seorang dokter dalam melakukan pekerjaannya wajib untuk memperhatikan aspek pelayanan kesehatan secara menyeluruh mulai dari upaya promotif, preventif, kuratif, dan rehabilitatif. Dokter juga perlu menjadi pendidik dan pengabdi masyarakat. Oleh karena itu, suatu upaya promotif juga merupakan salah satu kewenangan seorang dokter dan dalam pelaksanaannya juga perlu bekerja sama dengan aparatur lintas sektoral. Tidak hanya itu, kerja sama dari masyarakat juga berperan penting terhadap keberhasilan upaya promotif yang dilakukan. ${ }^{13}$

Penundaan kunjungan ke rumah sakit ini dibatasi oleh beberapa kondisi. Pada kondisi medis yang berpotensi gawat darurat, dokter wajib untuk melakukan pertolongan. ${ }^{13}$ Pada kondisi-kondisi tersebut masyarakat perlu diedukasi untuk segera melakukan kunjungan ke rumah sakit. Masyarakat perlu memahami bahwa menunda kunjungan ke rumah sakit pada kondisi tersebut dapat menyebabkan ancaman bagi nyawa pasien yang bersangkutan. Pada kondisi-kondisi tersebut pula, menekan risiko transmisi SARS-CoV-2 tidak menjadi fokus utama mengingat penyelamatan nyawa atau life saving menjadi prioritas utama dalam pelayanan kesehatan.

\section{KESIMPULAN}

Saat ini perlu dilakukan paya promotif melalui edukasi kepada masyarakat mengenai penundaan kunjungan ke rumah sakit kecuali pada kondisi dengan potensi gawat darurat. Hal ini diperlukan untuk menekan risiko transmisi virus SARS-CoV-2 dan mendukung upaya mematuhi protokol kesehatan di fasilitas layanan kesehatan.

\section{KONFLIK KEPENTINGAN}

Tidak ada konflik kepentingan.

\section{REFERENSI}

1. Peraturan Menteri Kesehatan Republik Indonesia nomor 1501 tahun 2010.

2. Undang-undang nomor 4 tahun 1984 .

3. Undang-undang nomor 29 tahun 2004.

4. Kementrian kesehatan RI. Profil kesehatan Indonesia tahun 2019. 2010.

5. United nations. World population prospects, the 2019 revision. 2019.

6. World health organization. Hospital preparedness for epidemics. 2014.

7. Gugus tugas percepatan penanganan COVID-19. Satuan tugas penanganan COVID-19. 21 August 2020.

8. Peraturan menteri kesehatan republik indonesia nomor 4 Tahun 2018

9. Farisa FC. Imbauan IDI untuk masyarakat, dokter, dan rumah sakit hadapi wabah covid-19[internet]. Mar 2020[diakses pada Agustus 2020]. Dapat diunduh di: https://nasional.kompas.com/ $\mathrm{read} / 2020 / 03 / 18 / 21501901 /$ imbauan-idiuntuk-masyarakat-dokter-dan-rumah-sakithadapi-wabah-covid-19? page $=$ all .

10. Kamus besar bahasa Indonesia daring. 2020.

11. Peraturan konsil kedokteran indonesia nomor 74 tahun 2020 tentang kewenangan klinis dan pratik kedokteran melalui telemedicine pada masa pandemi corona virus disease (covid-19) di indonesia.

12. Kementrian Kesehatan. Juknis pelayanan imunisasi pada masa pandemi covid-19. 2020.

13. Majelis kehormatan etik kedokteran. Kode etik kedokteran Indonesia. 2012. 